\title{
GUGUR DAUN TANAMAN KARET AKIBAT PENYAKIT PHYTOPHTHORA SPP. DI PERKEBUNAN KARET JEMBER, JAWA TIMUR
}

\author{
Incidence of Leaf Fall Caused by Phytophthora spp. on Rubber Tree in Jember, East Java \\ Intan Berlian dan Budi Setyawan \\ Balai Penelitian Getas, Pusat Penelitian Karet \\ J1. Pattimura KM 6, P.O. Box 804, Salatiga, Jawa Tengah, 50702 \\ Email : intan_balitgetas@yahoo.com
}

Diterima 4 Mei 2017 / Direvisi 19 September 2017 / Disetujui 25 September 2017

\begin{abstract}
Abstrak
Kebun Renteng dan Banjarsari merupakan bagian dari kebun milik PT. Perkebunan Nusantara XII yang terletak di Kabupaten Jember dengan komoditas utama tanaman karet. Mulai bulan Desember 2013, tanaman karet di Kebun Renteng Afdeling Sidomulyo tahun tanam (TT) 1996 dan Kebun Banjarsari Afdeling Karang Nangka TT 1993 mengalami gangguan gugur daun berulang. Penelitian dilakukan dari bulan Januari - Maret 2014. Identifikasi penyebab gugur daun didasarkan pada postulat Koch yang terdiri dari a) diagnosis penyebab penyakit yaitu mikroorganisme harus selalu menyertai gejala yang tampak; b) mikroorganisme harus dapat dipisahkan (diisolasi) dan dibiakkan dalam biakan murni bebas dari mikroorganisme lain; c) biakan murni hasil isolasi jika ditularkan pada tanaman sehat harus mengakibatkan gejala yang sama seperti awalnya; d) dari hasil tanaman yang ditulari tersebut, mikroorganisme harus dapat dipisahkan kembali (reisolasi) dan hasilnya harus sama dengan mikroorganisme yang dipakai untuk menularkan. Hasil identifikasi menunjukkan daun menguning yang disertai gugur daun di Afdeling Sidomulyo TT 1996 dan Afdeling Karang Nangka TT 1993 disebabkan patogen Phytophthora spp. Penyakit ini juga menyebabkan busuk buah karet. Penyakit ini didukung oleh curah hujan dan kelembaban yang tinggi. Pada saat penelitian berlangsung dan dua bulan sebelumnya, kedua afdeling tersebut mempunyai curah hujan tinggi,
\end{abstract}

kelembaban mencapai $90 \%$, temperatur minimum $22^{\circ} \mathrm{C}$ dan maksimum $29^{\circ} \mathrm{C}$ dengan kondisi tajuk yang saling menaungi. Penelitian ini membuktikan adanya serangan Phytophthora spp. yang menyebabkan gugur daun di Indonesia setelah laporan terakhir pada tahun 1977.

Kata kunci : karet, gugur daun, Phytophthora spp.

\section{Abstract}

Renteng and Banjarsari field are a part of PT. Perkebunan Nusantara XII, located in Jember district with major commodity of rubber plant. Since December 2013, leaf fall occurred in Renteng field Afdeling Sidomulyo (year of planted 1996) and Banjarsari field Afdeling Karang Nangka (year of planted 1993). The study have conducted in January to March 2014. Identification of the leaf fall caused Koch's postulates, which consist of: (a) the organism must be consistently associated with the lesions of the disease; (b) the organism must be isolated from the lesions and grown in pure culture; (c) the organism from pure culture must be re-inoculated into the healthy host and must cause the same disease as was originally observed; (d) the organism must be reisolated into culture and shown to be identical to the organism originally isolated. The results showed that yellowing of leaf that's accompanied by leaf fall in Afdeling Sidomulyo (year of planted 1996) and Afdeling Karang Nangka (year of planted 1993) caused by pathogen Phytophthora spp. This disease also causes the rot rubber fruit. The disease was supported by high rainfall and humidity. At the 
time of the study and two months before, the condition in both of afdeling has high rainfall, humidity reaches $90 \%$, minimum temperature $22^{\circ} \mathrm{C}$ and maximum $29^{\circ} \mathrm{C}$ with overshadow canopy. This study has been proved that Phytophthora spp. causes the leaf fall in Indonesia after the last reported in 1977.

\section{Keywords: Hevea, leaf fall, Phytophthora spp.}

\section{Pendahuluan}

Tanaman karet merupakan komoditas unggulan Indonesia yang menduduki urutan kedua setelah tanaman sawit. Luas perkebunan karet di Indonesia pada tahun 2015 mencapai 3.621.600 ha (Badan Pusat Statistik, 2017) yang tersebar di beberapa provinsi antara lain Sumatera Utara, Sumatera Selatan, Kalimantan Barat, Kalimantan Tengah, Kalimantan Timur, Jawa Barat, Jawa Tengah, Jawa Timur serta beberapa provinsi lain. Dalam usaha perkebunan karet terdapat beberapa kendala yang dihadapi salah satunya adalah penyakit tanaman dengan kerugian yang ditimbulkan bervariasi. Menurut data Dirjenbun tahun 2014, penyakit jamur akar putih mengakibatkan kerugian Rp 373.890.483.090,- sedangkan penyakit yang menyerang daun mengakibatkan kerugian $\mathrm{Rp}$ 48.585.877.035,-.

Pada umumnya, penyakit daun yang menyerang tanaman karet terdiri dari penyakit gugur daun (PGD) Oidium, Colletotrichum, dan Corynespora. Penyakit gugur daun Oidium (Oidium heveae) merupakan penyakit yang menyerang tanaman karet diakhir musim kemarau atau menjelang musim penghujan. Gejala penyakit berupa tepung putih yang menyelimuti daun menyebabkan permukaan daun mengeriput, ujung daun mengering dan akhirnya gugur (Soekirman \& Setyawan, 2007). Daun yang rentan terhadap $O$. heveae adalah (flush) berumur 1-9 hari. Serangan yang berat mengakibatkan gugur daun berulang kali, tanaman menjadi gundul, dan sebagai akibatnya produksi lateks menurun. Di Indonesia, klon karet yang tahan terhadap penyakit PDG Oidium adalah IRR 5, IRR 39, IRR 118, RRIC 100, BPM 1, BPM 24, BPM
107, BPM 109, IRR 32, IRR 42, IRR 104, IRR 112, PB 260, PB 330, PB 340 (Setiono et al., 2007).

Penyakit PGD Colletotrichum (Colletotrichum gloesporoides) yang menyerang tanaman karet pada musim hujan. Serangan $C$. gloeosporioides pada daun muda menimbulkan bercak berwarna coklat kehitaman pada bagian tengahnya, daun mengeriput, permukaan daun menjadi kasar, gugur daun dan die back (Soekirman \& Setyawan, 2007). PGD Colletotrichum dapat mengakibatkan gugur daun berulang jika PGD Oidium yang menyerang sebelumnya tidak dikendalikan sempurna. Di Indonesia, klon karet yang tahan terhadap penyakit PDG Colletotrichum adalah BPM 1, IRR 39, IRR 104, RRIC 100, BPM 24, BPM 107, BPM 109, IRR 5, IRR 32, IRR 118, PB 217, PB 260, PB 330, PB 340, AVROS 2037 (Setiono et al., 2007).

Penyakit gugur daun yang dapat menyebabkan kerusakan sepanjang tahun adalah PGD Corynespora (Corynespora cassiicola). Gejala serangan PGD Corynespora pada daun muda (flush) yang masih berwarna merah tembaga yaitu terjadi perubahan warna daun menjadi kuning, menggulung dan layu. Daun-daun akan terlepas dari tangkainya dan tangkai tersebut juga akan gugur. Pada daun muda, serangan Corynespora tidak menimbulkan bercak yang nyata, tetapi tampak kuning merata diseluruh permukaan daun. Sedangkan pada daun tua, serangan Corynespora ditandai dengan adanya bercakbercak tak beraturan berwarna coklat tua atau hitam, tampak menyirip seperti tulang ikan. Bagian sekitar bercak akan berubah menjadi jingga sampai ungu dan akhirnya daun gugur. Serangan pada tangkai dan tulang daun utama berupa bercak coklat kehitaman dan mengakibatkan gugur daun. Ranting muda yang terserang akan pecah, kering dan akhirnya mati (Soekirman \& Setyawan, 2007). Di Indonesia, klon karet yang tahan terhadap PDG Corynespora adalah BPM 1, BPM 24, BPM 109, IRR 32, IRR 39, IRR42, IRR 112, IRR 118, PB 340, BPM 107, IRR 5, IRR 104, PB 217, PB 260, PB 330, RRIC 100, AVROS 2037 (Setiono et al., 2007). 
Penyakit gugur daun pertama kali dilaporkan menimbulkan kerusakan pada tanaman karet di Sri Lanka (Ceylon) tahun 1905 (Jayarathnam et al., 1987), diikuti oleh India tahun 1910 pada perkebunan karet swasta di Kerala. Sangchote et al. (2004) melaporkan kejadian penyakit di barat daya pantai Thailand. Penyakit ini juga menyerang karet di Malaysia bagian utara dan barat (Johnston, 1989) serta Myanmar (Turner \& Myint 1980). Di Indonesia, penyakit daun akibat Phytophthora spp. pada tanaman karet tidak mempunyai arti penting dan keberadaan penyakit tersebut masih diragukan (Berita P4TM, 1984). Penyakit ini diduga pernah muncul di Jawa dan Sumatera Selatan tetapi hanya pada beberapa tempat tertentu dalam skala kecil. Pada tahun 1974 dilakukan penelitian untuk mencari penyakit gugur daun di Sumatra Utara tetapi tidak berhasil ditemukan (Turner, 1974) disitasi oleh Semangun (2004). Soepadmo (1978) pernah menemukan serangan gugur daun akibat spp. di Kebun Balong, Kabupaten Jepara, Jawa Tengah. Sejak penemuan tersebut sampai sekarang tidak ada laporan resmi tentang keberadaan penyakit daun akibat Phytophthora spp. pada tanaman karet maupun kerugian yang ditimbulkan.

Berbeda dengan di Indonesia, gugur daun akibat Phytophthora spp. dilaporkan menimbulkan kerugian pada perkebunan karet di India, Sri-Lanka, Burma, Cambodia, Vietnam, Liberia, Costa Rica, Venezuela, Malaysia dan Thailand (Omorusi et al., 2014). Serangan Phytophthora spp. pada perkebunan karet di India mengakibatkan pengurangan latek sampai $32 \%$ dan kerugian dapat menjadi 38 - 56\% jika tidak dilakukan pengendalian. Pada klon yang rentan, kehilangan hasil mencapai 40\% (Thanseem \& Thulaseedharan, 2006). Evaluasi kerugian produksi karena penyakit gugur daun yang disebabkan oleh Phytophthora spp. pada perkebunan karet klon RRIM 600, GT 1 dan RRII 118 yaitu masingmasing $31,66 \%, 8,21 \%$ dan $7,15 \%$. Di Thailand Selatan gugur daun Phytophthora mengakibatkan penurunan produksi lateks sampai 40\% (Drenth \& Sendall, 2004). Selain mengakibatkan pengurangan hasil latek, penyakit tersebut juga dapat menurunkan hasil kayu. Daun merupakan sumber fotosintesis untuk pertumbuhan dalam tanaman karet, maka jika terjadi pengurangan daun akibat gugur daun akan berdampak pada rendahnya ukuran diameter batang (Viswanathan et al., 2005).

Berdasarkan gejala penyakit yang menyerang tanaman maka perlu dilakukan identifikasi untuk mengetahui penyebab penyakit. Hasil identifikasi tersebut sangat bermanfaat untuk menentukan tindakan pengendalian yang tepat dan efektif. Menurut (Semangun, 2006) dan (Agrios, 2005), dalam mengidentifikasi penyakit tanaman harus melewati beberapa tahap uji, seseorang tidak boleh langsung menarik kesimpulan suatu mikroorganisme tertentu penyebab penyakit tersebut. Ada kemungkinan mikroorganisme itu hanya bersifat sekunder atau saprofitik yang hanya dapat masuk ke dalam jaringan setelah jaringan tersebut dilemahkan oleh mikroorganisme primer. Penyebab penyakit harus dibuktikan dengan dasar-dasar yang dibuat oleh Robert Koch atau sering disebut postulat Koch. Pembuktian harus meliputi, a) diagnosis penyebab penyakit yaitu mikroorganisme harus selalu menyertai gejala yang tampak; b) mikroorganisme harus dapat dipisahkan (diisolasi) dan dibiakkan dalam biakan murni bebas dari mikroorganisme lain; c) biakan murni hasil isolasi jika ditularkan pada tanaman sehat harus mengakibatkan gejala yang sama seperti awalnya; d) dari hasil tanaman yang ditulari tersebut, mikroorganisme harus dapat dipisahkan kembali (reisolasi) dan hasilnya harus sama dengan mikroorganisme yang dipakai untuk menularkan. Tujuan penelitian ini adalah untuk mengetahui penyebab gangguan yang menyerang tanaman karet di perkebunan karet Kebun Renteng dan Banjarsari. Hasil penelitian diharapkan dapat digunakan sebagai dasar langkah pengendalian yang tepat. 


\section{Bahan dan Metode}

Penelitian lapangan dilakukan di kebun milik PT. Perkebunan Nusantara XII Jawa Timur. Kebun yang digunakan adalah Kebun Renteng di Afdeling Sidomulyo tahun tanam (TT) 1996 dan Kebun Banjarsari di Afdeling Karang Nangka TT 1993. Tanaman karet yang ditanam di kedua kebun tersebut terdiri dari beberapa klon atau multiklon. Penelitian lanjutan dilakukan di Laboratorium Proteksi Balai Penelitian Getas dan rumah kaca. Penelitian dilakukan dari bulan Januari Maret 2014. Alat yang digunakan adalah seperangkat alat untuk isolasi jamur, gelas benda, D-glass, mikroskop, lup, kamera, plastik, kertas label. Bahan yang digunakan adalah bagian tanaman yang menunjukkan adanya gejala, media potato dextrose agar (PDA) untuk menumbuhkan jamur, lactofenol cotton blue, polibag, bibit karet umur 6 bulan. Data pendukung antara lain curah hujan, hari hujan, kelembaban diambil dari data kebun.

Metode yang digunakan untuk identifikasi penyakit mengacu pada postulat Koch dengan empat tahap pembuktian. Tahap pertama adalah diagnosis penyebab penyakit secara makroskopis dengan melihat gejala secara langsung di lapangan maupun dari sampel (bagian tanaman sakit) yang diambil. Selanjutnya dilakukan pengamatan mikroskopis dengan mengorek konidia jamur dari bagian yang bergejala penyakit dan diamati di bawah mikroskop. Tahap kedua adalah isolasi dari bagian tanaman sakit. Bagian tanaman karet sakit didesinfeksi dengan alkohol $75 \%$ kemudian dipotong antara jaringan sakit dengan jaringan sehat dan hasil potongannya diletakkan di dalam petridish yang telah berisi Potato Dextrose Agar (PDA) padat. Biakan dalam petridish tersebut diinkubasi dalam suhu kamar. Setelah miselium tumbuh, kemudian diidentifikasi di bawah mikroskop dan ditumbuhkan pada medium PDA baru untuk mendapatkan biakan murni dan disimpan di medium PDA agar miring. Tahap ketiga adalah inokulasi pada tanaman karet sehat. Biakan murni hasil isolasi ditumbuhkan dalam medium PDA selama 7 hari pada suhu kamar, kemudian digunakan untuk membuat suspensi spora dengan kerapatan $10^{6}$ spora/ml. Suspensi ini lalu diinokulasikan pada tangkai daun dan tunas tanaman karet sehat. Inkubasi dilakukan sampai menimbulkan gejala. Tahap keempat adalah reisolasi dari gejala penyakit yang muncul dari hasil inokulasi pada tanaman karet sehat dan diidentifikasi kembali.

\section{Hasil dan Pembahasan}

Kebun Renteng dan Banjarsari merupakan bagian dari kebun milik PT. Perkebunan Nusantara XII yang terletak di Kabupaten Jember dengan komoditas utama tanaman karet. Pada bulan Januari 2014, tanaman karet dikedua kebun tersebut mengalami gangguan yang diduga disebabkan oleh penyakit. Gangguan tersebut menyerang tanaman karet di Kebun Renteng Afdeling Sidomulyo tahun tanam (TT) 1996 (28,29 ha) dan Kebun Banjarsari Afdeling Karang Nangka TT 1993 (46,00 ha) (Gambar 1a). Secara umum gejala gangguan di Afdeling Sidomulyo TT 1996 mempunyai kemiripan dengan gejala di Afdeling Karang Nangka TT 1993 yaitu daun menguning, terdapat bercak kehitaman pada tangkai daun maupun ranting muda dan disertai gugur daun.

\section{Pengamatan Makroskopis dan Mikroskopis dari Gejala Serangan}

Fenomena gugur daun terjadi pada tanaman karet di Kebun Renteng Afdeling Sidomulyo TT 1996 dan Kebun Banjarsari Afdeling Karangnangka TT 1993. Gejala gugur daun terjadi pada daun yang masih berwarna hijau maupun daun-daun dewasa. Sebagian besar daun gugur masih melekat pada tangkai daun dan sebagian lagi sudah lepas dari tangkainya. Buah yang dihasilkan dari tanaman sakit tersebut terlihat berkeriput, berubah warna menjadi hitam dan mengering, sedangkan biji di dalamnya mengalami pembusukan dan berkeriput. Kondisi gugur daun yang terjadi di kedua Afdeling tersebut semakin parah dengan adanya curah hujan tinggi dan angin. 

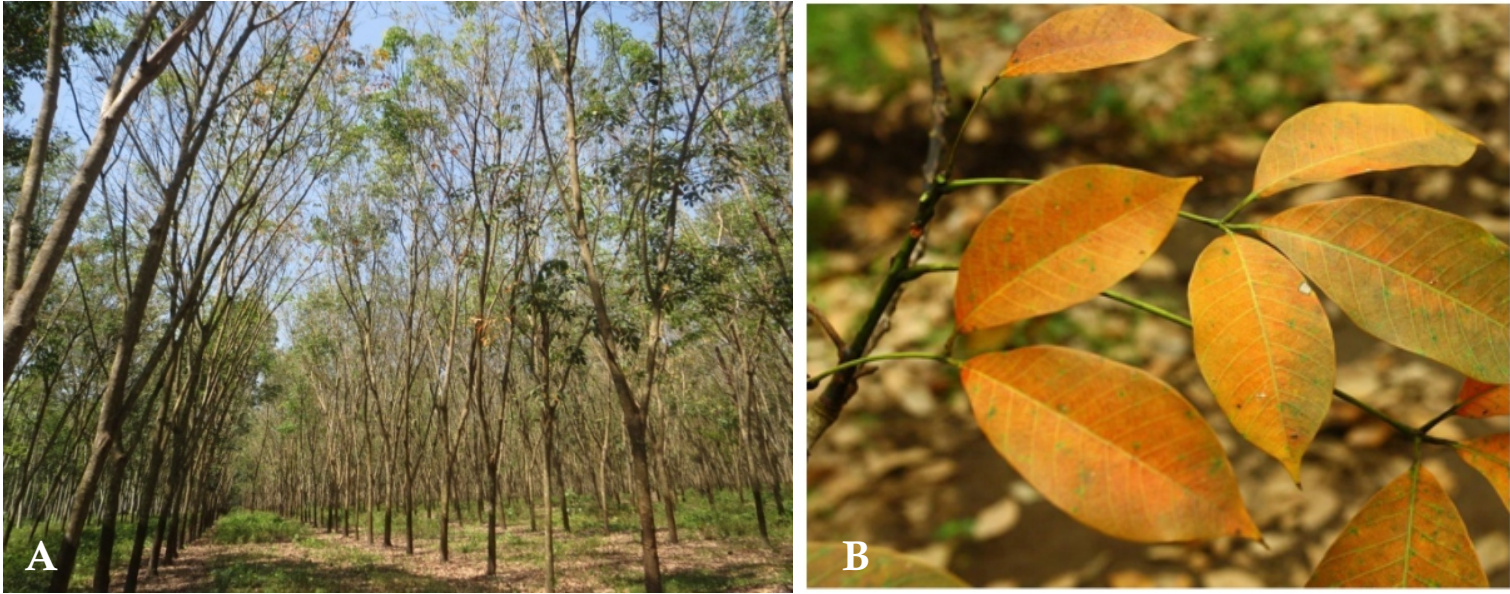

Gambar 1. Keragaan tanaman dengan kondisi tajuk sedang (A), daun menguning dan mudah rontok (B)

Identifikasi makroskopis gugur daun yang terjadi dibedakan menjadi dua macam berdasarkan ciri gejalanya. Gugur daun yang pertama mempunyai gejala berupa daun masih melekat pada tangkainya dan terlihat ada bercak coklat kehitaman di tangkai tersebut (Gambar 1b). Di tengah-tengah bercak terdapat bintik putih yang merupakan kumpulan lateks beku. Sedangkan gugur daun yang kedua mempunyai gejala daun sudah lepas dari tangkainya dan terlihat ada bercak coklat kehitaman di ibu tulang daun. Berdasarkan hasil identifikasi mikroskopis dengan cara mengorek langsung gejala tersebut kemudian dilihat di bawah mikroskop maka didapatkan spora berupa Phytophthora sp., Fusarium sp., dan Corynespora sp. (Gambar 2b).

Identifikasi juga dilakukan dengan cara mengisolasi gejala tersebut pada medium PDA dan diamati pertumbuhan sporanya dengan mikroskop, hasil isolasi didapatkan spora Phytophthora sp. Berdasarkan pengamatan makroskopis dari gejala penyakit serta hasil identifikasi mikroskopis maka diduga Phytophthora sp. merupakan patogen utama yang menyebabkan gugur daun, sedangkan Fusarium sp., dan Corynespora cassiicola hanya sebagai patogen minoritas atau saprofit. Spora jamur Phytophthora sp. juga ditemukan dari hasil isolasi pada bagian ranting muda atau dekat dengan tunas yang gejalanya hampir sama dengan di tangkai daun dan ibu tulang daun yaitu bercak coklat kehitaman (Gambar 3c). Menurut Soepadmo ( $\left.\begin{array}{llll}1 & 9 & 7 & 8\end{array}\right)$ dan Chirapongsatonkul et al. (2015) gejala penyakit gugur daun Phytophthora yaitu terdapat bercak coklat tua atau hitam pada tangkai daun dengan bintik putih di tengahnya yang merupakan lateks membeku. Pada umumnya bercak terdapat pada bagian pangkal tangkai daun dan kadang-kadang terdapat di ibu tulang daun maupun di ranting.

Diagnosis penyakit selanjutnya adalah mengambil sampel ranting tua dari Afdeling Sidomulyo TT 1996 dan Afdeling Karang Nangka TT 1993. Hasil pengamatan makroskopis sampel dari kedua tempat tersebut juga menunjukkan gejala yang sama. Gejala serangan berupa busuk kering dan jaringan mengalami nekrosis. Berdasarkan hasil identifikasi dengan mengorek langsung dan hasil isolasi dari bagian yang bergejala didapatkan spora Fusarium sp.

Hasil pengamatan makroskopis gejala serangan pada biji karet sampel dari Kebun Renteng Afdeling Sidomulyo TT 1996 dan Kebun Banjarsari Afdeling Karang Nangka TT 1993 juga menunjukkan gejala yang sama yaitu terjadi pembusukan sehingga mudah rontok. Berdasarkan hasil mengorek langsung dari gejala didapatkan patogen berupa Phytophthora sp., dan Fusarium sp., sedangkan dari hasil isolasi hanya didapatkan patogen 

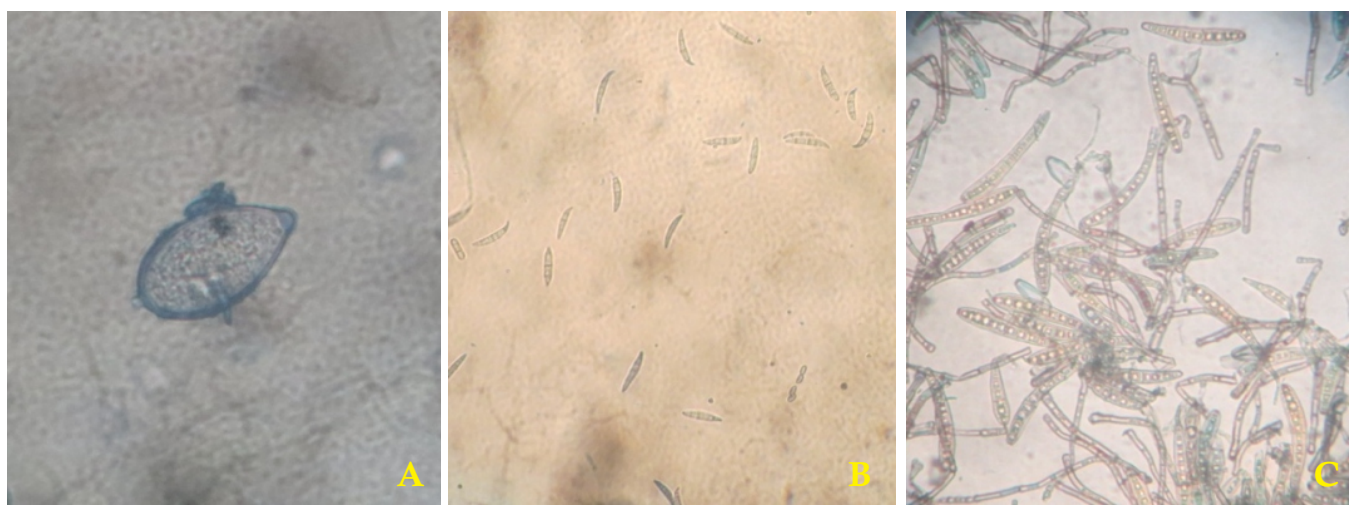

Gambar 2. Spora Phytophthora sp. (A), Fusarium sp. (B), dan Corynespora sp. (C) (perbesaran 400x)

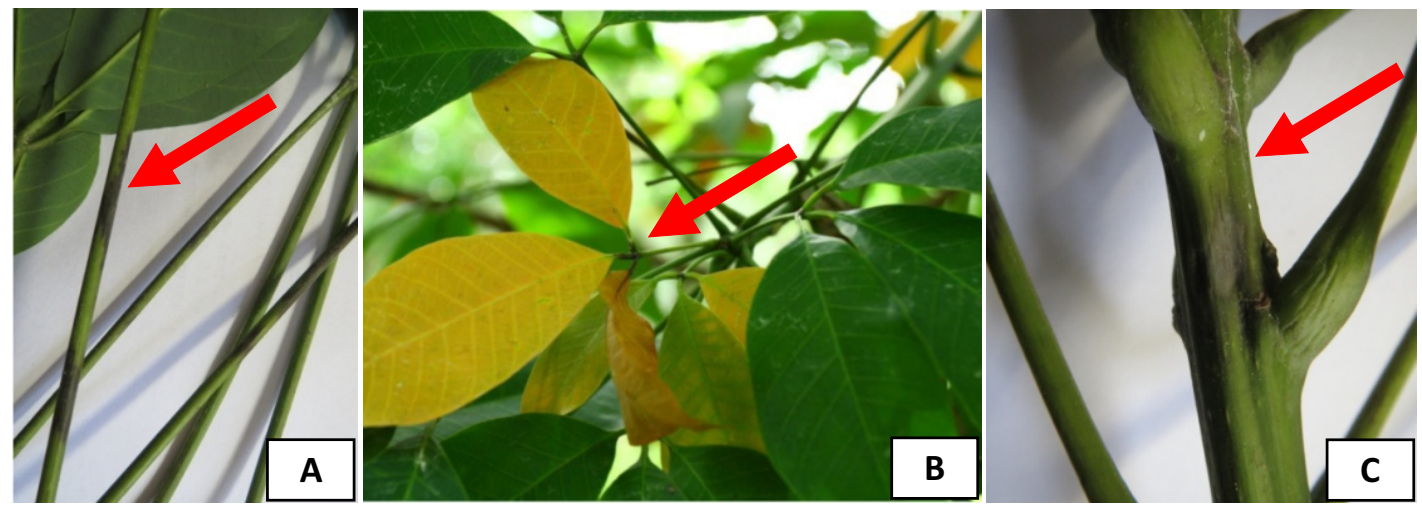

Gambar 3. Gejala bercak coklat/nekrosis pada tangkai daun (A), ibu tulang daun (B) dan ranting muda $(\mathrm{C})$

Phytophthora sp. Menurut Orellana (1959) serangan Phytophthora sp. pada buah menyebabkan buah busuk dan mudah rontok, kadang buah yang sakit masih tergantung di pohon, berwarna hitam, mengalami malformasi dan tidak pecah (Gambar 4). Jika buah pecah maka terlihat bijinya busuk dan keriput. Phytophthora spp. hanya dapat menginfeksi buah yang masih hijau, baik kecil maupun yang sudah besar (Semangun, 2004).

Gejala gangguan pada tanaman karet tidak hanya terjadi di Kebun Renteng Afdeling Sidomulyo TT 1996 dan Kebun Banjarsari Afdeling Karang Nangka TT 1993. Gejala gangguan juga muncul di Afdeling yang letaknya berdekatan tetapi masih TM muda yaitu di Kebun Renteng Afdeling Curah Manis
TT 2007 dan Kebun Banjarsari Afdeling Antokan TT 2007 (Gambar 5A \& 5B). Pada awalnya, gejala gangguan di Afdeling Curah Manis TT 2007 diduga tertular dari Afdeling Sidomulyo TT 1996 karena letaknya berdampingan. Namun setelah dilakukan pengamatan lebih lanjut ternyata keduanya mempunyai gejala berbeda. Gejala gangguan tanaman di Afdeling Curah Manis TT 2007 berupa daun menguning pada tajuk bagian bawah dan tidak disertai dengan bercak kehitaman pada tangkai daun maupun pada ranting muda dan tua. Buah dan biji yang dihasilkan terlihat normal dan tidak busuk. Gejala-gejala tersebut juga sama dengan tanaman di Afdeling Antokan TT 2007. 

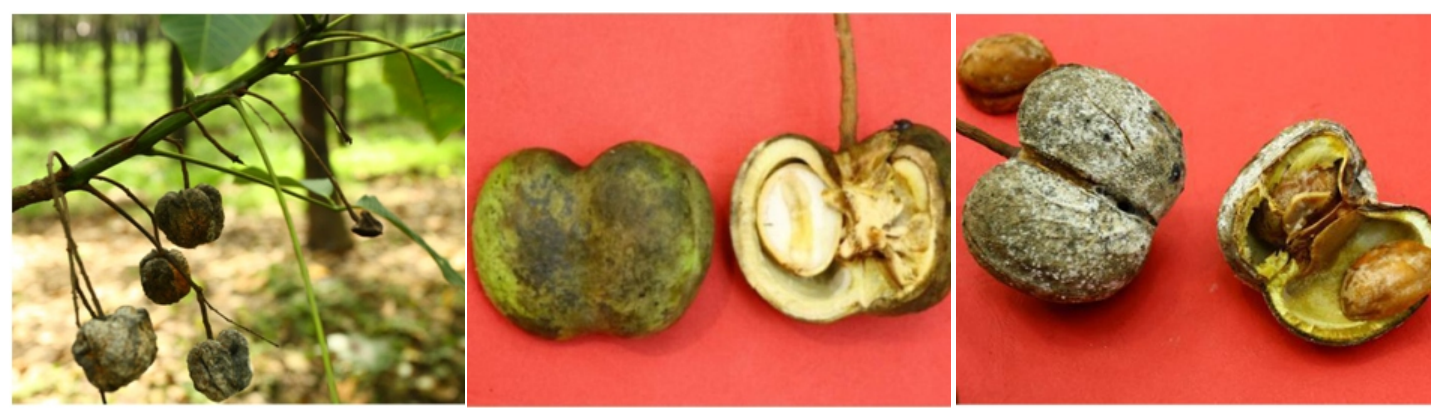

Gambar 4. Gejala serangan penyakit pada buah dan biji karet.
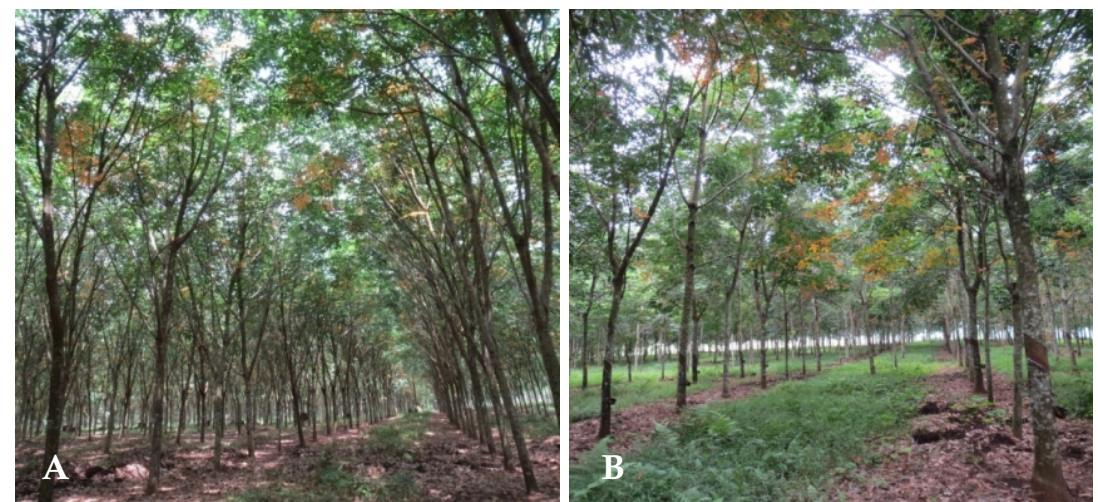

Gambar 5. Keragaan tanaman di Afdeling Curah Manis TT 2007 (A) dan Antokan TT 2007 (B)

Berdasarkan hasil analisis laboratorium dari daun yang menunjukkan gejala menguning dan identifikasi biji karet di Afdeling Curah Manis TT 2007 dan Antokan TT 2007 tidak ditemukan penyebab penyakit seperti di Afdeling Sidomulyo TT 1996 dan Afdeling Karang Nangka TT 1993. Beberapa daun di kedua TM muda tersebut hanya ditemukan gejala serangan penyakit daun Corynespora tetapi tidak banyak (Gambar 6a). Jika dilihat dari daun tua terlihat sebagian besar daun menunjukkan defisiensi unsur hara Kalium (K) dan Phosphat (P). Kekurangan unsur hara $\mathrm{K}$ ditandai dengan menguningnya bagian daun dari arah tepi kanan dan kiri daun berwarna kuning kemudian mengering sedangkan kekurangan unsur hara $\mathrm{P}$ ditandai dengan mengeringnya ujung daun dalam satu tangkai.

Menurut Shorrocks (1964) defisiensi unsur $\mathrm{K}$ pada tanaman karet dapat dilihat secara visual dan praktis dari gejala warna di daun. Tanda tersebut berupa tepi daun menguning atau mengering (nekrosa) pada daun tua (payung bawah). Jika defisiensi semakin berat daun akan menguning mudah rontok dan mengalami kematian pada tunas cabang. Gejala defisiensi unsur $\mathrm{K}$ nyata pada daun yang lebih tua karena mobilisasi kalium dari daun tua ke daun muda. Sedangkan gejala defisiensi unsur P berupa gejala bintik-bintik merah jingga di daun dan gejala terbakar (klorosis) pada bagian-bagian ujung helaian daun terutama pada daun yang sudah berkembang penuh (Gambar 6B).

\section{Postulat Koch}

Berdasarkan hasil isolasi awal dari gejala penyakit di Afdeling Sidomulyo TT 1996 dan Karang Nangka TT 1993 didapatkan isolat Phytophthora sp. dari tangkai daun maupun ranting muda yang mengalami bercak coklat kehitaman serta biji yang busuk, sedangkan isolat Fusarium sp. didapatkan dari ranting tua yang mengalami nekrosis. Kedua isolat 

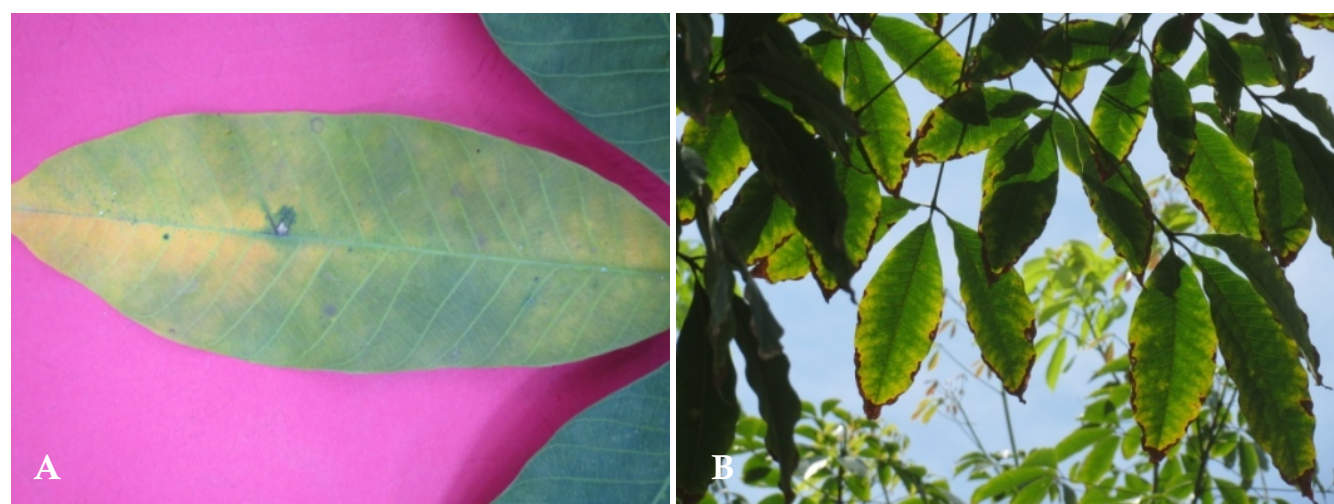

Gambar 6. Gejala penyakit gugur daun Corynespora (A), gejala defisiensi unsur hara $\mathrm{K}$ dan $\mathrm{P}$ pada daun (B).
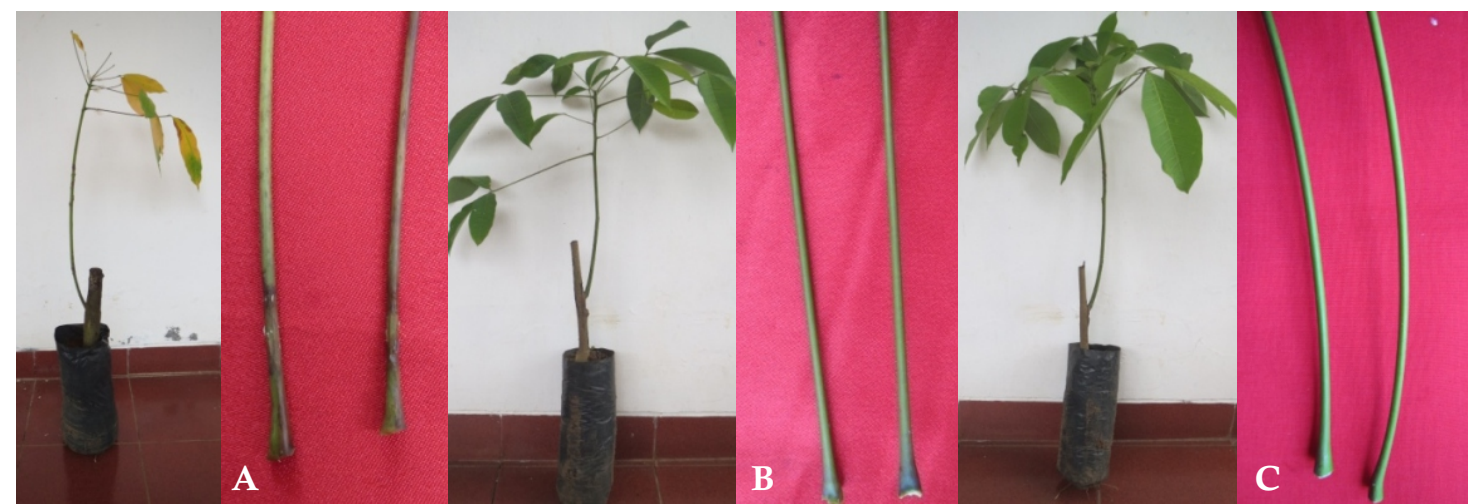

Gambar 7. Hasil postulat Koch dari inokulasi isolat Phytophthora sp.

(A), Fusarium sp. (B) dan kontrol (C)

tersebut kemudian digunakan untuk uji postulat Koch lebih lanjut. Spora Corynespora sp. yang didapat dengan mengorek langsung dari gejala penyakit di Afdeling Sidomulyo TT 1996, Karang Nangka TT 1993, Curah Manis TT 2007 dan Antokan TT 2007 tidak digunakan untuk uji postulat Koch karena hanya ditemukan di beberapa helaian daun. Uji postulat Koch dilakukan untuk membuktikan lebih lanjut apakah isolat yang didapat merupakan penyebab penyakit utama yang menyerang tanaman karet di Afdeling Sidomulyo TT 1996 dan Karang Nangka TT 1993.

Hasil postulat Koch dari inokulasi Phytophthora sp. pada tangkai daun tanaman karet sehat menunjukkan gejala yang sama dengan gejala serangan di lapangan yaitu terdapat bercak coklat kehitaman pada hari ke-
15 setelah inokulasi dan setelah dilakukan pengorekan langsung dari gejala serta mengisolasi kembali (reinokulasi) gejala tersebut didapatkan spora Phytophthora sp. Sedangkan dari hasil inokulasi Fusarium sp. pada tunas bibit karet sehat tidak menimbulkan gejala sampai hari ke-20 setelah inokulasi. Dari hasil reisolasi tunas tersebut juga tidak ditemukan patogen. Pada perlakuan kontrol tidak muncul bercak coklat kehitaman di tangkai daun maupun nekrosis dan juga tidak ditemukan jamur patogen. Hal ini membuktikan penyakit utama yang menyerang tanaman karet di Afdeling Sidomulyo TT 1996 dan Karang Nangka TT 1993 adalah Phytophthora spp. Menurut Thanseem \& Thulaseedharan (2006), sebagian besar spesies Phytophthora adalah patogen primer yang hanya menyerang tanaman sehat 
dengan cara menginfeksi jaringan tanaman sebelum organisme lain. Fusarium sp. diduga merupakan patogen sekunder yang menyerang tanaman ketika tanaman sudah lemah akibat serangan Phytophthora spp. Menurut Semangun (2004), Phytophthora spp. juga dapat menyerang ujung ranting dan menyebabkan daun-daunnya rontok. Organisme sekunder kemudian menginvasi ranting dan menyebabkan mati pucuk.

\section{Spesies Phytophthora dan Kisaran Inang}

Phytophthora spp. termasuk genus Oomycetes yang mempunyai 60 jenis spesies dengan kisaran inang luas (150 tanaman inang), antara lain karet, kakao, kayu manis, kelapa sawit, durian, jeruk, kentang, pepaya, lada, nanas, tomat, tembakau, talas, cabai, kapulaga, pala, alpukat, peach, plum, aprikot, cherry, dll (Anandaraj et al., 2015; Guest, 2015). Satu spesies Phytophthora dapat menjadi patogen untuk beberapa tanaman. Di China, meskipun spesies utama yang menyerang tanaman karet adalah $P$. citrophthora, tetapi spesies lain seperti $P$. palmivora, $P$. meadii, $P$. nicotianae dan $P$. capsici juga dapat menginfeksi tanaman tersebut (Zeng \& Ward, 1998). Di India, penyakit gugur daun karet dapat disebabkan $P$. meadii, $P$. botryosa, $P$. capsici, $P$. citrophthora, $P$. palmivora dan $P$. nicotianae, $P$. meadii meskipun pada umumnya disebabkan $P$. meadii (Roy \& Saha, 2015). Di Nigeria, umumnya penyakit daun karet disebabkan $P$.

Tabel 1. Beberapa spesies Phytophthora yang menyerang tanaman karet

\begin{tabular}{|c|c|c|}
\hline Spesies & Negara & Literatur \\
\hline \multirow[t]{3}{*}{ P. botryosa } & Malaysia & Chee (1968) \\
\hline & Thailand & Tsao et al., (1975) \\
\hline & Vietnam & Duong et al., (1998) \\
\hline \multirow[t]{2}{*}{ P. capsici } & Brazil & Dos Santos et al., (1995); Pereira et al., (1995) \\
\hline & China & Zeng \& Ward (1998) \\
\hline \multirow[t]{3}{*}{ P. citrophthora } & Brazil & Dos Santos et al., (1995) \\
\hline & China & Zeng \& Ward (1998) \\
\hline & Amerika Selatan & Jayasinghe (2001) \\
\hline \multirow[t]{5}{*}{ P. meadii } & India & Kochuthresiamma et al., (1988) \\
\hline & Myanmar & Johnston (1989) \\
\hline & Sri Lanka & Liyanage (1982); Jayatissa et al., (1994) \\
\hline & Malaysia & Thompson (1929) \\
\hline & Amerika Selatan & Jayasinghe (2001) \\
\hline \multirow[t]{8}{*}{ P. palmivora } & Brazil & Dos Santos et al., (1995); Pereira et al., (1995) \\
\hline & China & Zeng \& Ward (1998) \\
\hline & Malaysia & Chee (1969) \\
\hline & Sri Lanka & Dantanarayana et al., (1984) \\
\hline & Thailand & Tsao et al., (1975) \\
\hline & Vietnam & Duong et al., (1998) \\
\hline & Amerika Selatan & Jayasinghe (2001) \\
\hline & Nigeria & Okhuoya (1984) \\
\hline P. nicotianae & China & Zeng \& Ward (1998) \\
\hline P. heveae & Malaysia & Weir et al., (2015) \\
\hline
\end{tabular}

Sumber: Sdoodee (2004) 
palmivora tetapi juga dapat disebabkan $P$. botryosa, $P$. meadii, P. citrophthora, $P$. nicotianae dan P. capsici (Omorusi et al., 2014). Di Thailand, isolat Phytophthora spp. hasil isolasi dari tanaman durian juga dapat menginfeksi lada, kakao dan lebih agresif menginfeksi karet (Pongpisutta \& Sangchote, 2004). Di Indonesia, penyakit Phytophthora lebih banyak dilaporkan sebagai penyebab kanker bercak pada tanaman karet dan diketahui sebagai $P$. palmivora Soekirman \& Setyawan, 2007; Semangun, 2004).

\section{Daur Hidup dan Faktor Yang Mempengaruhi Perkembangan Penyakit}

Phytophthora spp. berkembang biak dengan cara aseksual dan seksual. Siklus hidup Phytophthora spp. seperti ditunjukkan pada Gambar 8 (Bartnicki-Garcia \& Wang, 1983). Pada keadaan lingkungan yang sesuai, sporangium matang hasil perkembangbiakan secara aseksual dapat langsung berkecambah membentuk tabung kecambah atau zoospora (spora kembar) berflagella/dapat bergerak. Zoospora akan berkecambah jika keadaan lingkungan mendukung dan akan membentuk struktur istirahat atau sista jika lingkungan tidak mendukung. Buah karet muda atau buah tua merupakan medium utama bagi jamur untuk berkecambah. Perkecambahan spora berlangsung pada suhu $20-28{ }^{\circ} \mathrm{C}$ dan suhu optimum untuk berhasilnya infeksi adalah $28^{\circ} \mathrm{C}$. Di lapangan, Phytophthora spp. akan berkembang cepat apabila suhu mencapai 29 ${ }^{0} \mathrm{C}$. Hasil perkecambahan zoospora berupa miselia dapat langsung menginfeksi melalui luka ataupun lubang alami. Selain secara aseksual, Phytophthora spp. juga dapat berkembang biak secara seksual yaitu dengan menghasilkan oospora. Oospora seksual terbentuk secara tunggal dalam oogonium setelah terjadi pembuahan oleh inti dari antheridium. Hasil perkembangbiakan seksual ini memungkinkan terjadi strain atau ras baru yang lebih virulen dibandingkan induknya. Oospora dan klamidospora mempunyai dinding sel yang lebih tebal dan keras untuk bertahan hidup ketika lingkungan kurang mendukung.

Penyebaran patogen terutama disebabkan oleh percikan air hujan. Menurut Soepadmo (1978) gugur daun akibat serangan Phytopthora spp. berlangsung terus dalam keadaan cuaca basah sehingga tanaman terlihat gundul sampai daun terbentuk pada musim berikutnya. Pada saat penelitian berlangsung, kondisi lingkungan di Afdeling Sidomulyo dan Karang Nangka dalam keadaan cuaca basah. Hal tersebut didukung oleh data curah hujan dan hari hujan di masing-masing Afdeling tersebut.

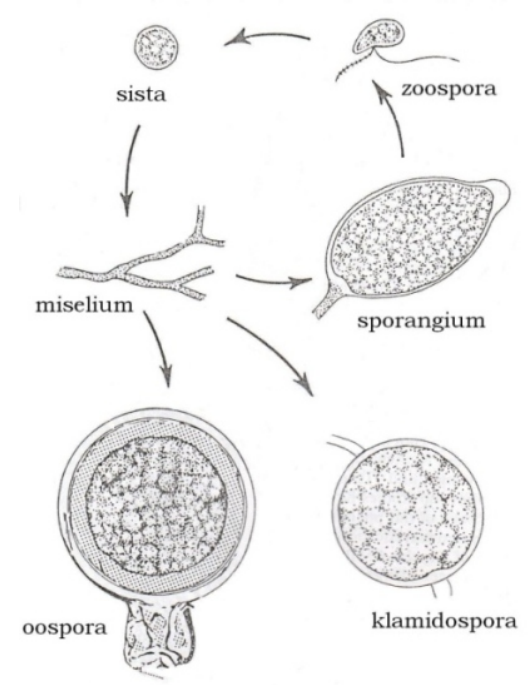

Gambar 8. Siklus hidup Phytophthora spp. 
Tabel 2. Data curah hujan dan hari hujan di Afdeling Sidomulyo dan Karang Nangka

\begin{tabular}{lcccc}
\hline \multirow{2}{*}{ Bulan } & \multicolumn{2}{c}{ Afdeling Sidomulyo } & \multicolumn{2}{c}{ Afdeling Karang Nangka } \\
\cline { 2 - 5 } & Curah h ujan $(\mathrm{mm})$ & Hari hujan (hh) & Curah hujan $(\mathrm{mm})$ & Hari hujan (hh) \\
\hline November 2013 & 194 & 18 & 671 & 23 \\
Desember 2013 & 522 & 20 & 875 & 23 \\
Januari 2014 & 360 & 16 & 543 & 22 \\
Februari 2014 & 95 & 12 & 180 & 15 \\
Maret 2014 & 178 & 10 & 337 & 16 \\
\hline
\end{tabular}

Berdasarkan data di atas, curah hujan yang terjadi ketika penelitian berlangsung dan dua bulan sebelumnya menunjukkan intensitas yang tinggi. Kelembaban di kedua Afdeling tersebut rata-rata mencapai $90 \%$, temperatur minimum $22^{\circ} \mathrm{C}$ dan maksimum $29^{\circ} \mathrm{C}$ dengan kondisi tajuk yang saling menaungi. Kondisi tersebut dapat menjadi pendukung terjadinya serangan penyakit gugur daun Phytophthora spp. ketika sudah ada inokulum. Phytophthora spp. mampu bertahan hidup di tanah atau bahan tanaman mati selama waktu tertentu ketika tanaman inang tidak ada dan akan menyerang tanaman pada saat inokulum mencukupi serta lingkungan mendukung (Bartnicki-Garcia \& Wang, 1983). Menurut Roy (2015), kondisi di lapangan yang mendukung infeksi Phytophthora spp. terhadap tanaman karet adalah curah hujan 250-350 $\mathrm{mm}$ pada periode 7-10 hari tanpa diselingi adanya panas sinar matahari dengan temperatur minimum $22-25^{\circ} \mathrm{C}$ dan maksimum 26-30 $0^{\circ} \mathrm{C}$ serta kelembaban 90\%. Kelembaban tinggi, temperatur rendah dan tajuk rimbun merupakan faktor predisposisi terjadinya penyakit dan penyebaran inokulum yang epifitotik(Omorusi et al., 2014).

\section{Pengelolaan Penyakit Gugur Daun Phytophthora spp.}

Pengendalian penyakit gugur daun Phytophthora spp. yang terjadi di Afdeling Sidomulyo dan Karang Nangka harus dilakukan secara terpadu mengingat kondisi lingkungan yang mendukung untuk berkembangnya patogen serta klon campuran yang tidak diketahui ketahanannya terhadap Phytophthora spp. Pengendalian Phytophthora spp. dapat dilakukan secara efektif dan efisien dengan program manajemen penyakit terpadu yang melibatkan aplikasi fungisida, praktek budidaya yang tepat dan peramalan penyakit. Menurut Keen \& Yoshikawa (1983) ketahanan terhadap Phytophthora spp. di lapangan ditentukan oleh interaksi antara inang, patogen dan lingkungan. Selain itu juga terdapat tiga komponen perlawanan terhadap Phytophthora spp. yaitu: a) ketahanan terhadap penetrasi, b) pembatasan pertumbuhan jamur pada tanaman inang, dan c) mengurangi sporulasi jamur pada tanaman inang. Konsentrasi atau jumlah inokulum dan kondisi lingkungan merupakan faktor yang dapat menentukan ketahanan inang dalam meminimalkan penyakit. Selain itu, efektivitas strategi pengendalian Phytophthora spp. juga tergantung pada kemampuan setiap spesies Phytophthora untuk bertahan hidup, baik sebagai saprofit atau sebagai spora aktif. Pada umumnya, miselium dan zoospora hanya bertahan beberapa minggu sedangkan klamidospora dapat bertahan selama 6 tahun, dan oospora bertahan selama 13 tahun (Erwin \& Ribeiro 1996).

Pengendalian penyakit Phytophthora spp. secara protektif dapat menggunakan bubur bordeaux yang terbuat dari kombinasi tembaga sulfat dan kalsium hidroksida. Bubur bordeaux merupakan salah satu fungisida tertua di dunia yang dirumuskan oleh Millardet pada tahun 1885 untuk mengendalikan patogen Plasmopara viticola (Oomycetes) penyebab downly mildew pada tanaman anggur. Fungisida tersebut melekat dengan baik pada daun, namun memiliki kelemahan kurang efisien dalam persiapan dan aplikasinya (Erwin \& Ribeiro 1996). 
Penyemprotan mineral oil yang mengandung tembaga oksiklorida diterapkan secara luas di India, Malaysia dan Sri Lanka sebagai tindakan preventif dalam manajemen penyakit gugur Phytophthora spp. (Jayasinghe \& Jayaratne 1996). Namun, aplikasi tersebut mempunyai kelemahan yaitu harganya mahal dan tidak praktis karena tanaman sudah tinggi serta mempunyai hamparan luas. Menurut Jacob et al. (1995) metalaksil, oxadixyl, captafol, folpet atau mancozeb direkomendasikan untuk mengendalikan kanker garis dan gugur daun akibat Phytopthora spp.

Pengendalian gulma dan perbaikan drainase perlu dilakukan untuk mengurangi kelembaban kebun terutama di daerah yang mempunyai curah hujan tinggi, hal ini mengingat curah hujan yang tinggi merupakan faktor penting penyebab keparahan penyakit. Perbaikan tanaman juga perlu dilakukan dengan pemberian bahan organik yang bertujuan untuk merangsang pertumbuhan akar tanaman, meningkat serapan hara, meningkatkan kapasitas lengas tanah, memperbaiki suhu tanah, dan menyediakan nutrisi untuk mikroba tanah (Aryantha et al., 2000). Menurut Lazarovits et al. (2001), amonia dan asam organik dari hasil pembusukan bahan organik dapat membunuh Phytophthora spp. dalam tanah sedangkan sisa bahan organik dapat merangsang mikroorganisme kompetitif dan antagonis dalam tanah. Penanaman tanaman penutup tanah juga dapat meningkatkan jumlah bahan organik yang mendorong pertumbuhan mikroba dan berperan menekan perkembangan Phytophthora spp. dalam tanah (Broadley, 1992).

Dalam beberapa kasus, intensitas penyakit dapat ditekan menggunakan pupuk lengkap terutama mengandung tiga hara esensial $(\mathrm{N}, \mathrm{P}$, $\mathrm{K})$. Pemupukan kalium (K) sering dianjurkan untuk mengurangi kerusakan akibat serangan jamur patogen. Kalium berfungsi untuk pengembangan dinding sel secara intensif dan korelasinya pada beberapa kasus resisten terhadap serangan penyakit (Bluter dan Jones, 1961). Menurut Wijaya (2002) pemupukan kalium berhubungan dengan ketahanan tanaman terhadap penyakit yaitu dengan meningkatkan ketebalan epidermis daun dan pengontrolan stomata yang lebih baik.

Alternatif pengendalian terhadap Phytophthora spp. secara biologis telah banyak dilakukan secara in vitro dan percobaan dalam polibag. Namun metode pengendalian ini belum banyak dilakukan pada tanaman karet. Menurut Galindo et al. (1992) serangan $P$. palmivora pada kakao dapat dikendalikan menggunakan antagonis seperti Bacillus spp., Aspergillus tamarii, A. gigentus, Botryodiplodia theobromae, Penicillium purpurescens dan Pseudomonas fluorescens). Menurut El-Tarabily et al. (1996), Trichoderma spp., Penicillium funiculosum, Gliocladium spp., Chaetomium globosum dapat menekan pertumbuhan $P$. cinnamomi dengan membuat lisis hifa. Mikoriza juga dapat digunakan sebagai pengendali biologi terhadap P. cinnamomi pada pinus (Marais \& Kotze 1976) dan nanas (Guillemin et al., 1994). Jamur endofitik seperti Trichoderma spp. juga dapat digunakan untuk melindungi kakao dari serangan Phytophthora spp. (Arnold et al., 2003).

Penggunaan bahan kimia secara terusmenerus untuk strategi pengendalian penyakit mengakibatkan dampak negatif terhadap lingkungan hidup. Menurut (Jayasinghe \& Jayaratne 1997) langkah pendekatan terpadu untuk manajemen penyakit Phytophthora spp. yaitu menekankan pada resistensi genetik. Skrining dan perbaikan genetik karet untuk ketahanan terhadap Phytophthora spp. telah dilaksanakan di Asia Tenggara. Beberapa klon toleran telah dibentuk dan berhasil ditanam di daerah endemis penyakit. Kedepannya, penggunaan klon tahan dapat dijadikan alternatif pilihan untuk tindakan pengendalian preventif. 
Tabel 3. Beberapa sifat ketahanan klon karet terhadap penyakit gugur daun Phytophthora spp.

\begin{tabular}{|c|c|c|}
\hline Klon & Ketahanan Klon & Literatur \\
\hline $\begin{array}{l}\text { PB 86, RRIC 45, RRIM } 600 \text { and RRIM } \\
602\end{array}$ & Rentan & $\begin{array}{l}\text { Liyanage et al., (1986); } \\
\text { Satchuthananthavale (1971) }\end{array}$ \\
\hline $\begin{array}{l}\text { RRII 105, GT 1, Gl 1, PB 86, PB 217, PB } \\
\text { 235, PB 260, PB 311, PB 28/59, RRIM } \\
\text { 600, RRIM 628, RRIM 703, PR 255, PR } \\
\text { 261, Tjir } 1\end{array}$ & Rentan & Narayanan \& Mydin (2011) \\
\hline $\begin{array}{l}\text { PR107, PB 86, RRIM 600, PB 310, PR } \\
255\end{array}$ & Rentan & Thanh et al., (2004) \\
\hline RRII 400, RRII 414 dan RRII 430 & Moderat & Narayanan \& Mydin (2011) \\
\hline RRIM 600 and RRIC 110 & Rentan & $\begin{array}{l}\text { Churngchow \& Rattarasarn, } \\
\text { (2001); Thanseem et al., (2005) }\end{array}$ \\
\hline BPM 24 & Tahan & $\begin{array}{l}\text { Churngchow \& Rattarasarn, } \\
\text { (2001); Thanseem et al., (2005). }\end{array}$ \\
\hline PR107 & Tahan & Thanh et al., (2004) \\
\hline
\end{tabular}

Sumber:Sdoodee (2004)

\section{Kesimpulan}

Gejala gangguan tanaman akibat penyakit di Kebun Renteng Afdeling Sidomulyo TT 1996 dan Kebun Banjarsari Afdeling Karang Nangka TT 1993 berupa daun menguning, bercak kehitaman pada tangkai daun maupun ranting muda, gugur daun dan busuk buah. Hasil identifikasi berdasarkan postulat Koch menunjukkan patogen penyebab penyakit tersebut adalah Phytophthora spp. Kejadian penyakit ini didukung oleh curah hujan tinggi dengan kelembaban mencapai $90 \%$, temperatur $22^{\circ}-29^{\circ} \mathrm{C}$ dan kondisi tajuk yang saling menaungi. Pengendalian penyakit harus dilakukan secara terpadu mengingat kondisi lingkungan yang mendukung untuk berkembangnya patogen serta klon campuran yang tidak diketahui ketahanannya terhadap Phytophthora spp. Penelitian ini membuktikan adanya serangan Phytophthora spp. yang menyebabkan gugur daun di Indonesia setelah laporan terakhir pada tahun 1977.

\section{Daftar Pustaka}

Agrios, G. N. (2005). Plant pathology ( $5^{\mathrm{h}}$ ed.). New York, USA: Elsevier Academic Press.
Anandaraj, M., Bhai, R. S., Eapen, S. J., Praveena, R., Nair, B., Jose, C., \& Rosana, O. B. (2015, 9-12 September ). Taxonomic investigations warrants re-description of Phytophthora species infesting black pepper in India. Tulisan disajikan pada $3 \mathrm{rd}$ International Symposium on Phytophthora : Taxonomy, Genomics, Pathogenicity, Resistance and Disease Management 2015, Bengaluru.

Arnold, A. E., Mejía, L. C., Kyllo, D., Rojas, E. I., Maynard, Z., Robbins, N., \& Herre, E. A. (2003). Fungal endophytes limit pathogen damage in a tropical tree. Proceedings of the National Academy of Sciences, 100(26), 15649-15654. doi:10.1073/pnas.2533483100

Aryantha, I., Cross, R., \& Guest, D. (2000). Suppression of Phytophthora cinnamomi in potting mixes amended with uncomposted and composted animal manures. Phytopathology, 90(7), 775-782. doi:10.1094/PHYTO.2000.90.7.775.

Badan Pusat Statistik. (2017). Luas Tanaman Perkebunan Menurut Propinsi dan Jenis Tanaman, Indonesia (000 Ha), 2012-2015. Jakarta, Indonesia: Badan Pusat Statistik. 
Bartnicki-Garcia, S., \& Wang, M. C. (1983). Biochemical aspects of morphogenesis in Phytophthora. In D. C. Erwin, S. BartnickiGarcia, \& P. H. Tsao (Eds.), Phytopthora Its Biology, Taxonomy, Ecology and Pathology (pp. 121 - 137). St Paul, Minnesota: APS Press.

Bluter, S. E. J., \& Jones, S. G. (1961). Plant Pathology. London, England: Macmillan and Co Ltd.

Broadley, R. (1992). Protect your avocados. Brisbane, Australia: Queensland Government. Departement of Primary Industries.

Chirapongsatonkul, N., U-taynapun, K., Chanwun, T., \& Churngchow, N. (2015). Development of a multiplex PCR assay for rapid and simultaneous detection of rubber tree pathogens Phytophthora spp. and P. palmivora. Science Asia, 41(2015), 170-179. doi: $10.2306 /$ scienceasia 1513 1874.2015.41.170

Direktorat Jenderal Perkebunan. (2015). Data Luas Serangan OPT Karet Nasional dan Taksasi Kerugian Hasil. Jakarta, Indonesia: Direktorat Jendral Perkebunan, Kementerian Pertanian.

Drenth, A., \& Sendall, B. (2004). Economic impact of Phytophthora diseases in Southeast Asia. In A. Drenth \& D. I. Guest (Eds.), Diversity and Management of Phytophthora in Southeast Asia (pp. 10 - 28). Canberra, Australia: Australian Centre for International Agricultural Research.

El-Tarabily, K. A., Sykes, M. L., Kurtböke, I. D., Hardy, G. E. S. J., Barbosa, A. M., \& Dekker, R. F. (1996). Synergistic effects of a cellulase-producing Micromonospora carbonacea and an antibiotic-producing Streptomyces violascens on the suppression of Phytophthora cinnamomi root rot of Banksia grandis. Canadian Journal of Botany, 74(4), 618-624. doi:10.1139/b96-078

Erwin, D. C., \& Ribeiro, O. K. (1996). Phytophthora diseases worldwide. St Paul, Minnesota: American Phytopathological Society (APS Press).
Galindo, J., Keane, P., \& Putter, C. (1992). Prospects for biological control of black pod of cacao. In P. J. Keane \& C. A. J. Putter (Eds.), Cocoa pest and disease management in Southeast Asia and Australasia. Rome: FAO Plant Production and Protection Paper 112.

Guest, D. I. (2015, 9 - 12 September). Management of Phytophthora diseases in the tropics. Tulisan disajikan pada $3 \mathrm{rd}$ International Symposium on Phytophthora : Taxonomy, Genomics, Pathogenicity, Resistance and Disease Management 2015, Bengaluru.

Guillemin, J.-P., Gianinazzi, S., GianinazziPearson, V., \& Marchal, J. (1994). Contribution of arbuscular mycorrhizas to biological protection of micropropagated pineapple (Ananas comosus (L.) Merr) against Phytophthora cinnamomi Rands. Agricultural science in Finland, 3(3), 241-251.

Jacob, C. K., Edathil, T. T., \& Indicula, S. P. (1995). Management of black stripe disease of Hevea Indian Journal of Natural Rubber Research, 8, 21 - 24.

Jayarathnam, K., Rao, S. S., Jacob, C. K., \& Thomson, T. E. (1987). Prophylactic spraying against abnormal leaf fall disease: essential or not. Rubber Board Bulletin, 23, 24 $-28$.

Jayaratne, R., \& Jayasinghe, C. (1997). Impact of management strategies of Hevea diseases on the environment. Bulletin of Rubber Research Institute Sri Lanka, 35, 19-21.

Jayasinghe, C., \& Jayaratne, A. (1996). Phytophthora epidemics-possibility of management using resistant clones. Journal of the Rubber Research Institute of Sri Lanka, 77, 66-67.

Johnston, A. (1989). Diseases and pests. In C. C. Webster \& W. J. I. Baulkwil (Eds.), Rubber (pp. 415 - 458). New York, USA: Longman Scientific and Technical

Keen, N. T., \& Yoshikawa, M. (1983). Physiology of disease and the nature resistance of Phytophthora. In D. C. Erwin, S. Bartnicki-Garcia, \& P. H. Tsao (Eds.), Phytopthora Its Biology, Taxonomy, Ecology and Pathology (pp. 279 - 287). St. Paul, Minnesota: APS Press. 
Lazarovits, G., Tenuta, M., \& Conn, K. L. (2001). Organic amendments as a disease control strategy for soilborne diseases of high-value agricultural crops. Australasian Plant Pathology, 30(2), 111-117. doi:10.1071/AP01009

Marais, L., \& Kotze, J. (1976). Ectomycorrhizae of Pinus patula as biological deterrents to Phytophthora cinnamomi. South African Forestry Journal, 99(1), 35-39.

Omorusi, V. I., Eguavoen, I. O., Bosah, B. O., Ogbebor, O. N., Orumwense, K., Ijie, K., \& Okundia, R. O. (2014). Severity of Phytophthora leaf infection on some Rubber (Hevea brasiliensis) clones in Nigeria. Sci-Afric Journal of Scientific Issues, Research and Essays, 2(6), 289- 291.

Orellana, R. (1959). Variation in Phytophthora palmivora isolated from cacao and rubber. Phytopathology (EUA), 49, 210-213.

Pongpisutta, R., \& Sangchote, S. (2004). Morphological and Host Range Variability in Phytophthora palmivora from Durian in Thailand. In A. Drenth \& D. I. Guest (Eds.), Diversity and Management of Phytophthora in Southeast Asia (pp. 53-58). Canberra, Australia: Australian Centre for International Agricultural Research.

Roy, C. B. (2015, 9 - 12 September). Phytophthora diseases of rubber. Tulisan disajikan pada 3rd International Symposium on Phytophthora : Taxonomy, Genomics, Pathogenicity, Resistance and Disease Management 2015, Bengaluru.

Roy, C. B., \& Saha, T. (2015, 9 - 12 September). Towards understanding the extent of genetic diversity of Phytophthora spp. infecting rubber (Hevea brasiliensis) and deploying molecular markers for resistance breeding. Tulisan disajikan pada 3rd International Symposium on Phytophthora : Taxonomy, Genomics, Pathogenicity, Resistance and Disease Management 2015, Bengaluru.
Sangchote, S., Poonpolgul, S., Sdoodee, R., Kanjanamaneesathian, M., Baothong, T., \& Lumyong, P. (2004). Phytophthora Diseases in Thailand. In A. Drenth \& D. I. Guest (Eds.), Diversity and Management of Phytophthora in Southeast Asia (pp. 77 - 82). Canberra, Australia: Australian Centre for International Agricultural Research.

Sdoodee, R. (2004). Phytophthora diseases of rubber. In A. Drenth \& D. I. Guest (Eds.), Diversity and Management of Phytophthora in Southeast Asia (pp. 136 - 142). Canberra, Australia: Australian Centre for International Agricultural Research.

Semangun, H. (2004). Penyakit-Penyakit Tanaman Perkebunan di Indonesia. Yogyakarta, Indonesia: Gadjah Mada University Press.

Semangun, H. (2006). Pengantar ilmu penyakit tumbuhan. Yogyakarta, Indonesia: Gadjah Mada University Press.

Setiono., Rouf, A., \& Admojo, L. (2007). Manajemen Kebun Entres Karet. Salatiga, Indonesia: Balai Penelitian Getas.

Shorrocks, V. M. (1964). Mineral deficiencies in hevea and associated cover plants. Kuala Lumpur, Malaysia: Rubber Research Institute Malaya.

Soekirman, P., \& Setyawan, B. (2007). Pengenalan dan Pengendalian Penyakit Tanaman Karet. Salatiga, Indonesia: Balai Penelitian Getas.

Soepadmo, B. (1978). Beberapa penyakit daun pada tanaman karet dan cara mengendalikannya. Menara Perkebunan, 46(3), 111 - 116.

Thanseem, I., Joseph, A., \& Thulaseedharan, A. (2005). Induction and differential expression of -1,3-glucanase mRNAs in tolerant and susceptible Hevea clones in response to infection by Phytophthora meadii. Tree physiology, 25(11), 1361-1368. doi:10.1093/treephys/25.11.1361 
Thanseem, I., \& Thulaseedharan, A. (2006). Optimization of RQRT-PCR protocols to measure beta-1, 3-glucanase mRNA levels in infected tissues of rubber tree (Hevea brasiliensis). Indian journal of experimental biology, 44(6), 492-498.

Turner, P., \& Myint, U. H. (1980). Rubber diseases in Burma. FAO Plant Protection Bulletin, 28(3), 85-91.

Turner, P. D. (1974). Diseases of oil palm, rubber and cocoa in North Sumatra. Diakses dari Third Report UNDP/FAO Project INS/72/004 Strengthening research on rubber and oil palm in North Sumatra, Working Paper 32, pp.27.
Viswanathan, P. K., Kadavil, T. G., \& Jacob, C. K. (2005). Crop loss in rubber due to abnormal leaf fall: an analysis on the economic feasibility of plant protection measures in India. Journal of Plant Protection Research, 45(4), 235-248.

Wijaya, T. (2002). Rekomendasi pemupukan tanaman karet PT. Perkebunan Mitra Ogan untuktahun 2002. Diakses dari Palembang.

Zheng, F., \& Ward, E. (1998). Variation within and between Phytophthora species from rubber and citrus trees in China, determined by polymerase chain reaction using RAPDs. Journal of Phytopathology, 146(2-3), 103-109. doi:10.1111/j.14390434.1998.tb04665.x 